\title{
Variations in Division of Sciatic Nerve and its Clinical Relevance: A Cadaveric Study
}

\author{
Shalom Elsy Philip ${ }^{1}$, Dakshayani K. R ${ }^{2}$ \\ ${ }^{1}$ Senior Resident, Department of Anatomy, Christian Medical College, Ludhiana, ${ }^{2}$ Professor and Head, Department of Anatomy, Mysore Medical College, \\ Mysore.
}

\section{Abstract}

Introduction: The sciatic nerve emerges through the greater sciatic foramen, leaves pelvis and enters into gluteal region by passing below piriformis as a single nerve encompassed by a single epineural sheath. It descends along back of thigh and divides into tibial nerve and common peroneal nerve, usually at superior angle of popliteal fossa. Understanding of variations in the levels of division of sciatic nerve is important for the management of non- discogenic sciatica, posterior hip operations, failed sciatic nerve block. Objective: To study the variations in division of sciatic nerve and to define the level of its exit. Subjects and Methods: Seventeen cadavers (34 limbs) fixed in formalin were dissected and studied during routine dissection in department of Anatomy, Mysore Medical College and level of division of sciatic nerve were noted. Results: Out of 34 limbs, 5 cases (14.7\%) were dividing at gluteal region, 2 cases (5.8\%) at mid-thigh and 27 cases (79.4\%) exited pelvis as a whole nerve and divided at superior angle of popliteal fossa. Type $\mathrm{G}$ was most common variation. Conclusion: The exit and level of division of sciatic nerve is important for surgeons as there is surgical maneuvering in this region during posterior hip operations and to avoid iatrogenic nerve injury during deep intramuscular injections in gluteal region.

Keywords: Sciatic nerve, Tibial nerve, common peroneal nerve.

Corresponding Author: Dr. Shalom Elsy Philip, Senior resident, Department of Anatomy, Christian Medical College, Brown road, Ludhiana, Ludhiana, Punjab- 141008

Received: August 2019

Accepted: August 2019

\section{Introduction}

The sciatic nerve is the thickest nerve in the body. It leaves the pelvis via the greater sciatic foramen below piriformis and descends between the greater trochanter and ischial tuberosity, along the back of the thigh, dividing into the tibial and common fibular nerves at a varying level proximal to the knee. ${ }^{[1]}$ The common site of division of sciatic nerve is at the junction of the middle and lower thirds of the thigh, near the apex of the popliteal fossa, seen in $80 \%-90 \%$ of individuals but the division may occur at any level above this point, and it is variable. These variations may cause nerve compressions under other structures leading to non discogenic sciatica, piriformis syndrome, ${ }^{[2]}$ nerve injury during deep intramuscular injections in gluteal region, ${ }^{[3]}$ failed popliteal nerve block in anesthesia. ${ }^{[4]}$ The anatomical variations of the level at which the sciatic nerve divides is considered important by clinicians during neuromuscular diagnosis and treatments in lower limb. The present study is undertaken to know the incidence in variations of division of sciatic nerve in relation to piriformis in south Indian population.

\section{Subjects and Methods}

The study was carried out on 34 formalin fixed lower limbs (males: 24, females: 10) during routine dissection in department of Anatomy, Mysore Medical College for a period of three years. The division of sciatic nerve were evaluated for possible variations. The gluteal region, back of the thigh and popliteal fossa were exposed by dissection. The gluteus maximus muscle was cut from its insertion and reflected towards its origin. The biceps femoris muscle was retracted and the nerve was then exposed in popliteal fossa. The course of the nerve was delineated and looked for any possible variations. The exit of the nerve from pelvis, its relation to piriformis and level of division of the nerve were recorded under the following1) at level of gluteal region (high division) in relation to piriformis, 2) intermediate division 3) at the level of superior angle of popliteal fossa.

\section{Results}

Among the 34 limbs studied, a total of 7 limbs showed variations in the division of the nerve. All the variations were seen in male cadavers. 5 cases $(14.7 \%)$ were dividing at gluteal region of which 4 were of type $G$ variety ( 2 bilateral and 2 unilateral) where the tibial nerve and common peroneal nerve passes below piriformis(FIG-1) and one of Type $\mathrm{C}$ was seen unilaterally where common peroneal nerve was seen to arise above the piriformis and 


\section{Philip \& Dakshayani, Variations in Diwisian of Sciatic Nerue and its Clinical Relevance}

tibial nerve below(FIG-2). Intermediate division was seen bilaterally in 2 cases (5.8\%) approximately at upper thigh (FIG-3) and 27 cases (79.4\%) were of Type A variety which showed normal division at superior angle of popliteal fossa. Trifurcation of the nerve was not observed in any of the cases. [Table 1]

Table 1: Distribution of levels of division of sciatic nerve
\begin{tabular}{|l|l|l|l|}
\hline Laterality & Level of division & \\
\hline & $\begin{array}{l}\text { Gluteal } \\
\text { region }\end{array}$ & Intermediate & $\begin{array}{l}\text { Superior angle of } \\
\text { Popliteal fossa }\end{array}$ \\
\hline Bilateral & Type G(2) & 2 & Type A (24) \\
\hline Unilateral & Type $\mathrm{C}(1)$ & Nil & Type A(3) \\
\cline { 2 - 2 } & Type G(2) & & \\
\hline
\end{tabular}

Table 2: Comparison of incidence of variations of sciatic nerve with previous studies.

\begin{tabular}{|c|c|c|c|c|c|c|c|c|}
\hline $\begin{array}{l}\text { SL. } \\
\text { No }\end{array}$ & Authors & $\begin{array}{l}\text { Ty } \\
\text { pe } \\
\text { A }\end{array}$ & $\begin{array}{l}\text { Ty } \\
\text { pe } \\
\text { B } \\
\end{array}$ & $\begin{array}{l}\text { Ty } \\
\text { pe } \\
\text { C } \\
\end{array}$ & $\begin{array}{l}\text { Ty } \\
\text { pe } \\
\text { D }\end{array}$ & $\begin{array}{l}\text { Ty } \\
\text { pe } \\
\text { E }\end{array}$ & $\begin{array}{l}\text { Ty } \\
\text { pe } \\
\text { F }\end{array}$ & $\begin{array}{l}\text { Ty } \\
\text { pe } \\
\text { G }\end{array}$ \\
\hline 1 & $\begin{array}{l}\text { Beaton } \\
\text { and } \\
\text { Anson }^{[8]}\end{array}$ & $\begin{array}{l}84 . \\
\%\end{array}$ & $\begin{array}{l}11.7 \\
\%\end{array}$ & $\begin{array}{l}3.3 \\
\%\end{array}$ & $\begin{array}{l}0.8 \\
\%\end{array}$ & Nil & nil & Nil \\
\hline 2 & \begin{tabular}{l}
\multicolumn{2}{l}{ Tomasze } \\
wski et \\
al $^{[9]}$
\end{tabular} & $\begin{array}{l}85.2 \\
\%\end{array}$ & $\begin{array}{l}9.8 \\
\%\end{array}$ & $\begin{array}{l}1.9 \\
\%\end{array}$ & $\begin{array}{l}<1 \\
\%\end{array}$ & Nil & $\begin{array}{l}<1 \\
\%\end{array}$ & $\begin{array}{l}<1 \\
\%\end{array}$ \\
\hline 3 & $\begin{array}{l}\text { Ugrenovi } \\
\text { c et al }{ }^{[10]}\end{array}$ & $\begin{array}{l}96 \\
\%\end{array}$ & $\begin{array}{l}2.5 \\
\%\end{array}$ & $\begin{array}{l}1.5 \\
\%\end{array}$ & nil & Nil & nil & Nil \\
\hline 4 & $\begin{array}{l}\text { Bergman } \\
\text { et al }{ }^{[7]}\end{array}$ & $\begin{array}{l}87.5 \\
\%\end{array}$ & $\begin{array}{l}12 \\
\%\end{array}$ & $\begin{array}{l}0.5 \\
\%\end{array}$ & $\begin{array}{l}2.25 \\
\%\end{array}$ & Nil & nil & Nil \\
\hline 5 & $\begin{array}{l}\text { Pokorny } \\
\text { et al }{ }^{[11]}\end{array}$ & $\begin{array}{l}79.1 \\
\%\end{array}$ & $\begin{array}{l}14.3 \\
\%\end{array}$ & $\begin{array}{l}4.4 \\
\%\end{array}$ & $\begin{array}{l}2.2 \\
\%\end{array}$ & Nil & nil & Nil \\
\hline 6 & $\begin{array}{l}\text { Natsis et } \\
\mathrm{al}^{[13]}\end{array}$ & $\begin{array}{l}89.8 \\
\%\end{array}$ & $\begin{array}{l}6.1 \\
\%\end{array}$ & $\begin{array}{l}0.7 \\
\%\end{array}$ & $\begin{array}{l}0.7 \\
\%\end{array}$ & Nil & $\begin{array}{l}0.7 \\
\%\end{array}$ & Nil \\
\hline 7 & $\begin{array}{l}\text { Berihu et } \\
\mathrm{al}^{\left[{ }^{116]}\right.}\end{array}$ & $\begin{array}{l}75 \\
\%\end{array}$ & Nil & $2 \%$ & nil & Nil & nil & $9 \%$ \\
\hline 8 & $\begin{array}{l}\text { Sinha } \\
\mathrm{al}^{[12]}\end{array}$ et & $\begin{array}{l}85 \\
\%\end{array}$ & $9 \%$ & $9 \%$ & $3 \%$ & Nil & nil & Nil \\
\hline 9 & $\begin{array}{l}\text { Patel et } \\
\mathrm{al}^{[17]}\end{array}$ & $\begin{array}{l}91.8 \\
\%\end{array}$ & $\begin{array}{l}5.81 \\
\% \\
\end{array}$ & nil & nil & Nil & nil & $\begin{array}{l}2.32 \\
\% \\
\end{array}$ \\
\hline 10 & $\begin{array}{l}\text { Present } \\
\text { study }\end{array}$ & $\begin{array}{l}74.4 \\
\%\end{array}$ & Nil & $\begin{array}{l}2.9 \\
\% \\
\end{array}$ & nil & Nil & nil & $\begin{array}{l}11.7 \\
\%\end{array}$ \\
\hline
\end{tabular}

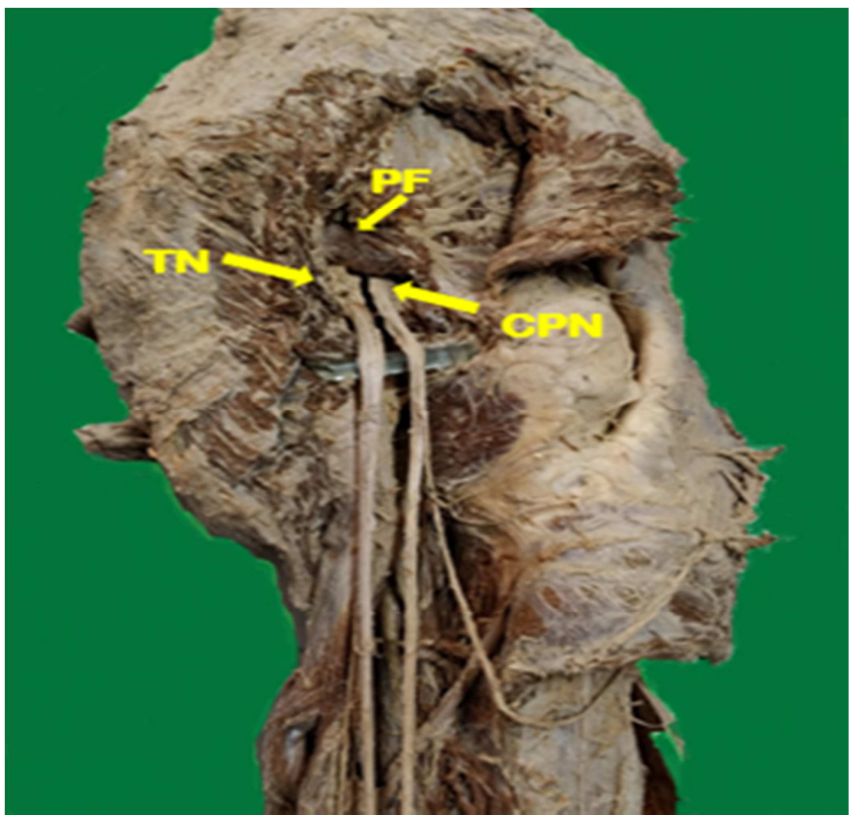

Figure 1: Type $G$ variation showing $T N$ and $C P N$ dividing below Piriformis (PF)

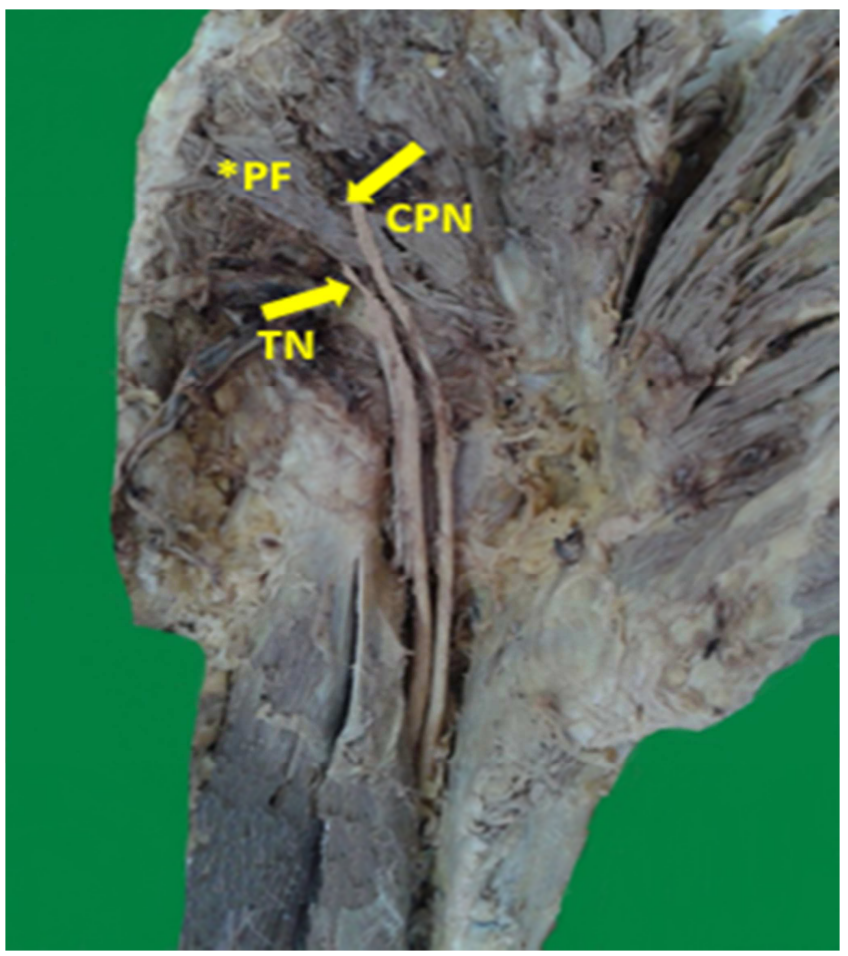

Figure 2: Type $\mathrm{C}$ variation showing $\mathrm{CFN}$ passes above the $\mathrm{PF}$ while the TN runs below

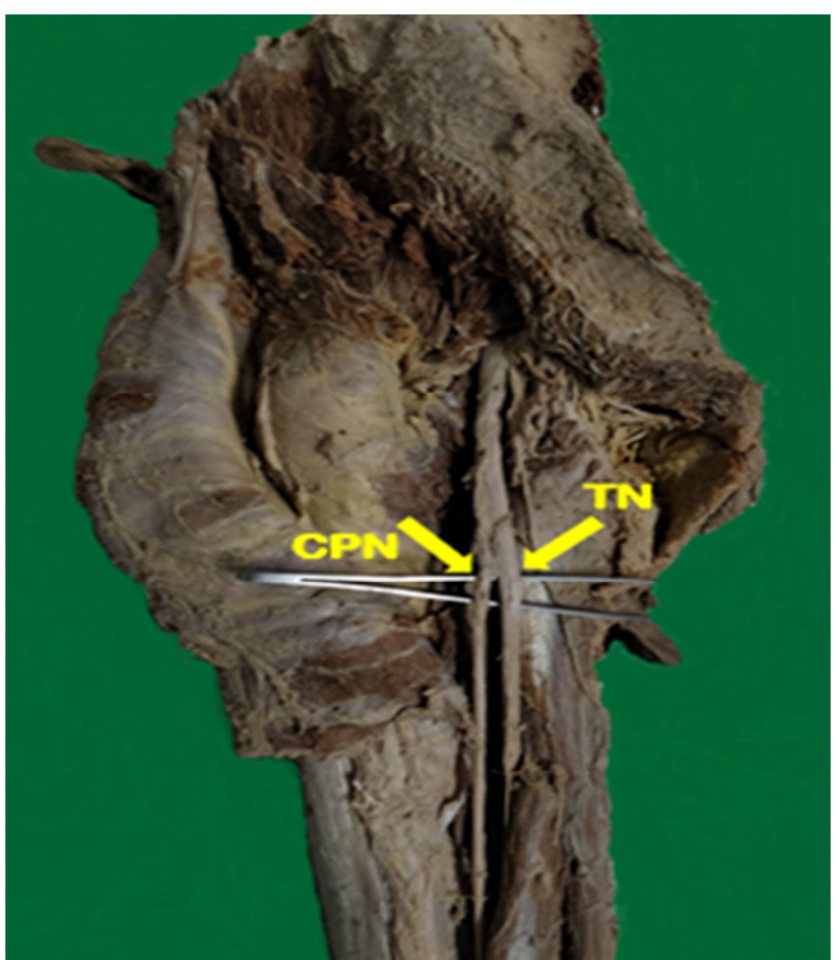

Figure 3: Variation of Sciatic nerve showing Intermediate division

\section{Discussion}

Sciatic nerve is a mixed nerve and the largest branch of lumbosacral plexus. It is formed by ventral rami L4-S3 of the spinal nerves, and at the base of the limb bud they are subdivided into dorsal and ventral components, to provide 
innervation for the appropriate muscle compartment as they follow the growth cones of the limb bud. ${ }^{[5]}$ Sciatic nerve presents significant variations concerning its division owing to its embryological basis as both components of the plexus move closely together downwards. ${ }^{[6]}$ The tibial and common peroneal nerve may directly arise from sacral plexus. ${ }^{[7]}$

Based on the literature, Beaton and Anson, ${ }^{[8]}$ has classified the variation of sciatic nerve in relation with piriformis and it was modified by Tomaszewski et al. ${ }^{[9]}$ The present study was done according to modified classification and is as follows: Type A- The sciatic nerve(SN) passes below the piriformis(PF) (most common), Type B-The $\mathrm{SN}$ divides in the pelvis, the common peroneal nerve $(\mathrm{CPN})$ pierces the $\mathrm{PF}$ and the tibial nerve(TN) passes below the PF ,Type C-The $\mathrm{SN}$ divides in the pelvis, the CFN passes above the PF, while the TN runs below. Type D-The SN pierces the PF. Type E-The SN divides in the pelvis, the CFN runs over the $\mathrm{PF}$, and the TN pierces the PF. Type F-The SN exits the pelvis undivided above the PF. Type G-The SN divides in the pelvis, the CFN and the TN courses separately below the $\mathrm{PF}$.

The different types of variations accounts for the early division of the nerves at their origins and their subsequent courses below. The variations with its frequency is shown in [Table 2]. In the present study, most commonly seen was type A (79.4\%) where the sciatic nerve passes below piriformis and divided at the level of superior angle of popliteal fossa, it was in par with the literature although Chiba et al, ${ }^{[14]}$ and Moore and Dalley, ${ }^{[15]}$ mentioned type B as commonly seen, $34 \%$ and $12.2 \%$ respectively. The second most common variation noted in the gluteal region was type $\mathrm{G}(11.7 \%)$ which was similar to study of Berihu et al, ${ }^{[16]}$ whereas type B was reported in literature. It was followed by type C (2.9\%) and the highest incidence of type C (16\%) was reported by Machado et al. ${ }^{[18]}$ Babinski et al, ${ }^{[25]}$ described a rare variation in which the CPN passed superior and $\mathrm{TN}$ inferior to superior gemellus muscle. A case report of double superior gemellus and double piriformis muscles associated with SN dividing and passing between two piriformis has been described by Arifoglu et al, ${ }^{[26]}$ These variations make the nerve vulnerable to compression, leading to neurological defects like piriformis syndrome, coccygodynia and muscle atrophy.

Intermediate division of sciatic nerve was noted in $5.8 \%$ where the division was at upper thigh which was different with the study of Kumar et al, ${ }^{[19]}$ and Kiros et al, ${ }^{[20]}$ who reported $14 \%$ and $12 \%$ respectively. Prakash et al, ${ }^{[21]}$ has reported as low as $3.5 \%$.In the present study, the high and intermediate divisions of sciatic nerve $(20.5 \%)$ were seen in males which differed from the study of Patel et al, ${ }^{[17]}$ reported variations in $3.12 \%$ of males and $22.72 \%$ in females. Ewa Okraszewska, ${ }^{[22]}$ reported no correlation of sciatic nerve variation with the sex. The variations were found unilaterally in 3 cases and bilaterally in 2 cases. There is no significant difference in laterality.

The high division may account for failures in popliteal nerve block. Popliteal block is usually given by insertion of the needle at $100 \mathrm{~mm}$ above the popliteal crease. Saleh et al, ${ }^{[24]}$ observed that SN division occurs at a variable level 50$180 \mathrm{~mm}$ above the popliteal fossa and may account for failures with popliteal block anesthesia. The variation of sciatic nerve can be the cause of iatrogenic nerve injury during intramuscular injections in gluteal region. ${ }^{[3]}$ It may also account to recurrent symptoms and refractory to treatment in patients with symptomatic lumbar disc herniation and sciatic neuropathy following total hip replacement. ${ }^{[23]}$

\section{Conclusion}

The anatomic variations of the sciatic nerve should be considered during procedures of gluteal region and thigh flap reconstructive surgeries to avoid iatrogenic injuries. The present study recorded a higher percentage of Type G compared to other literature. Proper understanding of these variants allow surgeons and radiologists to provide early intervention and better treatment outcome in south Indian population.

\section{References}

1. Standring S. The anatomical basis of clinical practice. In:Gray's Anatomy. 40th Ed. London: Elsevier Churchill Livingstone; 2008:p1384.

2. Parlak A, Aytekin A, Develi S, Ekinci S. Piriformis Syndrome: A case with non-discogenic sciatalgia. Turkish Neurosurgery 2014; 24(1):117-119.

3. Mishra P, Stringer MD.Sciatic nerve injury from intramuscular injection:A Persistent And Global Problem.Int J Clin Pract.2010;64(11):1573-9.

4. Jerry V, Admir H, Ernest A.The division of the sciatic nerve in the popliteal fossa: Anatomical implications for popliteal nerve blockade. Anesth Analg 2001; 92:215-217.

5. Moore K, Persaud T, Torchia M.The Developing Human: Clinically Oriented Embryology. 10th Edn. Saunders, Philadelphia.2015

6. Demiryurek D, Bayramoglu A, Erbil M, Aldur MM, Mustafa ES. Bilateral divided piriformis muscle together with the high division of the sciatic nerve. Gazi Med J 2002; 13:41-44.

7. Bergman RA, Afifi AK, Miyauchi R. Compendium of Human Anatomical Variations. Baltimore, Urban And Schwarzenberg 1988:p146

8. Beaton L, Anson B. The relation of the sciatic nerve and of its subdivisions to the piriformis muscle. Anat Rec. 1937; 70: 1-5.

9. Tomaszewski KA, Graves MJ, Henry BM, Popieluszko P, Roy J, Pękala P et.al. The Surgical Anatomy of the Sciatic Nerve: A MetaAnalysis. J Orthop Res, 2016; 34(10):1820-1827.

10. Ugrenovic S, Jovanovic L, Krstic V, Stojanovic V, Vasovic L, Antic $\mathrm{S}$ et.al. The level of the Sciatic nerve division and its relations to the piriform muscle. Vojnosanit Pregl, 2005;62(1): 45-49.

11. Pokorny D, Jahoda D, Veigl D, Pinskerova V, Sosna A.Topographic variations of the relationship of the Sciatic nerve and the piriformis muscle and its relevance to palsy after Total Hip Arthroplasty. Surg Radiol Anat, 2006; 28: 88-91.

12. Sinha MB, Aggarwal A, Sahni D, Harjeet K, Gupta R, Sinha HP. Morphological variations of Sciatic nerve and piriformis muscle in gluteal region during fetal period. Eur J Anat, 2014; 18(4): 261-266.

13. Natsis K, Totlis T, Konstantinidis GA, Paraskevas G, Piagkou M, Koebke J. Anatomical Variations Between The Sciatic Nerve And The Piriformis Muscle: A Contribution To Surgical Anatomy In Piriformis Syndrome. Surg Radiol Anat, 2014; 36: 273-280.

14. Chiba S, Ishibashi Y, Kasai T .Multiple positional relationships of nerves arising from the sacral plexus to the piriformis muscle in humans. Kaibogaku Zasshi, 1992; 67(6): 691-724.

15. Moore KL, Dalley AF.Clinical Oriented Anatomy, 4th Ed.Baltimore: Lippincott Williams\&Wilkins, 1999: p 558.

16. Berihu BA, Debeb YG. Anatomical variation in bifurcation and trifurcations of sciatic nerve and its clinical implications: in selected university in Ethiopia. BMC Res Notes, 2015; 8: 633.

17. Patel S, Shah M, Vora R, Zalawadia A, Rathod S. A variation in the 


\section{Philip \& Dakshayani; Variations in Diwisian of Sciatic Nerwe and its Clinical Relevance}

high division of the sciatic nerve and its relation with piriformis muscle. National J Med Res, 2011;1(2):27-30.

18. Machado F, Babinski M, Brasil F, Favorito L, Abidu-figueiredo M, Costa M. Anatomical variations between sciatic nerve and piriform muscle during fetal period in human. Int J Morphol, 2003; 21(1): 2935 .

19. Kumar T M., Srimathi, Rani A, Latha S. A cadaveric study of sciatic nerve and its level of bifurcation. J Clin Diag Res, 2011; 5:1502 $\square 4$.

20. Kiros MD, Woldeyes DH. Anatomical variations in the level of bifurcation of the sciatic nerve in Ethiopia. J Exp Clin Anat $2015 ; 14: 1-4$

21. Prakash, Bhardwaj AK, Devi MN, Sridevi NS, Rao PK, Singh G. Sciatic nerve division: A cadaver study in the Indian population and review of the literature. Singapore Med J 2010; 51:721-723.

22. Ewa O, Lukasz M, Kazimierz S , Wojciech B: Sciatic nerve variations in some studies on the Polish population and its statistical significance, Folia Morphol 2002: 61(4); 277-282.

23. Suri P, Rainville J, Hunter DJ, Li L, Katz JN: Recurrence of radicular pain or back pain after non-surgical treatment of symptomatic lumbar disc herniation. Arch Phy Med Rehabil 2012, 93:690-5.

24. Saleh HA, El-fark MM, Abdel GA. Anatomical variation of sciatic nerve division in popliteal fossa and its implication in popliteal nerve blockade. Folia Morpho 2009:68;256-259.

25. Babinski MA, Machado FA,Costa WS.A rare variation in the high division of sciatic nerve surrounding the superior gemellus muscle. Eur J Morphol 2003:41:41-42.

26. Arifoglu Y, Surucu HS, Sargon MF, Tanyeli E, Yazar F. Double superior gemellus together with double piriformis and high division of the sciatic nerve.Surg Radiol Anat 1997:19;407-408.

Copyright: () the author(s), publisher. Academia Anatomica International is an Official Publication of "Society for Health Care \& Research Development". It is an open-access article distributed under the terms of the Creative Commons Attribution Non-Commercial License, which permits unrestricted non-commercial use, distribution, and reproduction in any medium, provided the original work is properly cited.

How to cite this article: Philip SE, Dakshayani KR. Variations in Division of Sciatic Nerve and its Clinical Relevance: A Cadaveric Study. Acad. Anat. Int. 2019;5(2):11-14.

DOI: dx.doi.org/10.21276/aanat.2019.5.2.4

Source of Support: Nil, Conflict of Interest: None declared. 